\title{
Abortion among women living with or not living with HIV/AIDS users of public health services in São Paulo municipality: prevalence, contexts and reasons
}

Adriana de Araujo Pinho 1

https://orcid.org/0000-0003-2219-1066

Wilza Vieira Villela 2

https://orcid.org/0000-0002-6246-2716

Regina Maria Barbosa 3

https://orcid.org/0000-0002-3390-2137

Simone Souza Monteiro 4

D https://orcid.org/0000-0003-2009-1790

\footnotetext{
1 Instituto de Estudos em Saúde Coletiva. Universidade Federal do Rio de Janeiro. Av. Horácio Macedo, s.n. Ilha do Fundão. Cidade Universitária. CEP: 21.941-598. Rio de Janeiro, RJ, Brasil. E-mail: adrianaapinho@gmail.com

2 Consultora independente. São Paulo, SP, Brasil.

3 Núcleo de Estudos de População Elza Berquó. Universidade Estadual de Campinas. Campinas, SP, Brasil.

${ }_{4}^{4}$ Laboratório de Educação em Ambiente e Saúde. Fundação Oswaldo Cruz - Fiocruz, Rio de Janeiro, RJ, Brasil.
}

\begin{abstract}
Objectives: we investigated the lifetime prevalence of abortion and life contexts and reasons reported for first abortion among women living (WLHA) and not living with HIVIAIDS (WNLHA).

Methods: representative samples of 975 users of public health care reference network for HIV/AIDS and of 1,003 users of the primary care public services in São Paulo municipality were selected by cluster-stratified sampling and answered an electronic socio-behavioral questionnaire.

Results: the prevalence of abortion was 11.9\% (CI95\%9.8-13.9) among WLHA and $3.0 \%$ (CI95\%2.4-5.7) for WNLHA.Most abortions (128) among WLHA occurred before diagnosis and 28 after diagnosis or during pregnancy when diagnosis was given. The majority of women did not use any contraception at the time of the first abortion. The use of misoprostol was the most reported method. Having HIV was very important in deciding to abort for half of the WLHA. Absence of marital life and the lack of desire to have children were the most reported reasons by both groups.

Conclusions: the similarity in contexts and reasons to abort among WLHA and WNLHA suggests that they share experiences molded by gender and social inequalities that affect their ability to access sexual and reproductive health resources and services.
\end{abstract}

Key words Abortion, HIV, Reproductive health

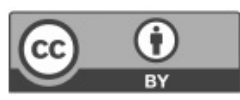




\section{Introduction}

The Brazilian scenario is far from offering worthy attention to sexual health and reproductive conditions (SHR). Despite the improvement of some indicators in the last 20 years, such as the decreasing of maternal mortality ${ }^{1}$ coefficients, sociodemographic and regional differentials persist, which reflect social inequalities in SHR. Besides, illnesses, such as breast cancer, persist with high incidence and mortality rates, ${ }^{2}$ while others, such as congenital syphilis, have increased more than threefold between the years 2006 and 2016, ${ }^{3}$ however, with regional variations. Caesarian section continues to predominate, with $53.4 \%$ of prevalence, according to the study Nascer no Brasil (Childbirth in Brazil), being many times associated to obstetric violence4 episodes. In addition to this unfavorable profile is the emergence of new illnesses, such as the circulation of Zika virus, which has a causal connection with the occurrence of the syndrome associated with congenital Zika virus infection. 5

As for reproductive planning, despite the growing use of contraception in last decades, a high proportion of unplanned pregnancies remains, 6 suggesting the existence of obstacles other than access to contraceptive methods. Stemming from the high magnitude of unplanned pregnancies, abortion continues a common practice, in a context where clandestinely-illegality often exposes women to risks.According to estimates based in hospitalization rates, in 2013, 12 to 16 abortions were induced among 1,000 women aged 15 to 49 years in Brazil, representing 687,347 to 865,160 abortions that year. 7 Considering the latest estimate of unsafe abortion in the world, Brazil answers for 15 to $18.8 \%$ of these cases in South America. 8

According to Diniz et al., ${ }^{9}$ one in each 5 Brazilian women at the age of 40 has had an abortion, being higher among those who declared themselves black, brown or indigenous, with low education and resident in the North, Northeast and CenterWest regions. Martin-Melo et al. 10 estimated, based on hospitalization registers from 1996 to 2012, the occurrence of 17 abortions per 1,000 women in reproductive age and 33 abortions for each 100 live births, with North, Northeast and East regions presenting the higher rates and ratios for abortions. Numbers can be even higher, given the underreporting of this practice, due to stigmatization and its criminalization.

Difference in abortion estimates among women living with HIV/Aids (WLHA) and women not living with HIV/Aids (WNLHA) is also observed, despite similarities in their determinants. Pilecco et $a l ., 11$ from representative samples of women users of primary care public services and specialized in attention to HIV/Aids in Porto Alegre, found that abortion was higher among WLHA. On the other hand, Barbosa et al., 12 based on WLHA convenience sample of different Brazilian regions, pointed out that there were no statistically significant differences between WLHA and WNLHA in the proportion of lifetime induced abortion, after adjustmentfor age, number of children and number of sexual partners. WLHA and WNLHA reported similar profiles, without differences in magnitude of the effects of their association.

Pinho et al. 13 identified important distinctions in the sexual and reproductive trajectories of WLHA, when compared to WNLHA users of public health services in the city of São Paulo. After adjustments for age, schooling and color of skin, the report of lifetime abortion was significantly higher for WLHA than for WNLHA $(12 \%$ versus $3 \%, p<0,0001)$, even considering separately abortions performed before and after diagnosis (15.8\% and 6.1\%, respectively). This result was attributed to the higher vulnerability observed in sexual and reproductive trajectories of WLHA.

Besides estimating the magnitude of abortion among WLHA and comparing it to that observed in WNLHA, it is relevant to analyze life contexts surrounding those abortions, their reasons and decisive factors for practicing it and the importance of HIV infection in the process. Therefore, these were the objectives of the present study, which also estimated the underreport the of induced abortion rate in WLHA and WNLHA samples.

\section{Methods}

Data for this analysis are from the "GENIH Study: Gender and infection by HIV: practices and decisions related to sexual and reproductive health", a cross-sectional quantitative study carried out in São Paulo municipality between February 2013 and May 2014 , with a representative sample of WLHA and a comparative sample of women users of the primary care health services, called WNLHA, with ages between 18 and 49 years. 13

The sample size was estimated at 1,000 for each group of women, considering the design effect (deff) by complex sampling equal to 1.6. An additional number of interviews were conducted $(25 \%)$ as a safetymargin for possible losses or refusal. To compose the WLHA sample, 18 public reference units in attending WLHA were included, responsible 
for $95 \%$ of assistance to people living with HIV/Aids in São Paulo city. These units constituted the strata, with the sample of 1,000 women distributed by each strata using proportional partition, according to the average number of monthly WLHA consultations from 18 to 49 years old. In each unit, women were randomly selected from a list ofdaily appointments. Considering a percentage of losses (refusals and users not found) of $25 \%, 1,368$ women were selected.

The WNLHA were drawn by means of a stratified two-stage cluster sampling process. The strata were formed by the five Regional Coordinators of Health of the Municipality of São Paulo (MSP) and the sample sharing was proportional to the size of these regions, given by the sum of average monthly numbers of medical and nursing consultations of their basic health units. For the draw, units were sorted by the existence or not of the Family Health Strategy, in order to obtain a stratified sample also by this variable. Thirty-eight services were drawn of a total of 442 ; three services in the central-west region, nine services in the east region, eight in the north region, five in the east region and thirteen services in the south region which aggregated the highest number of medical and nursing appointments in the MSP primary care network. Women were drawn from a list of scheduled appointments and fitins on interview days with a pre-defined interval. A greater number of interviews were drawn considering the percentage of women who would not participate in the research (refusal and not found users) would be $25 \%$; thus, 1,334 women were drawn among those eligible who showed up at the units.

The eligible WLHA and WNLHA who agreed to participate in the study were directed to a private room where the informed consent form was applied. After signing it, a social-behavioral electronic questionnaire was administered with the aid of a netbook. The electronic questionnaires were generate during the software QDSTM (Questionnaire Development System, by New Research Company) and pretested.

Considering that significant differences between the average number of predicted appointments compared to the current daily appointments could exist, new estimates of this frequency were obtained at each service, three days before field entry for both samples. Sample fractions were, then, altered based on this data and weighted in the data analysis step to compensate for these changes.

Study instruments and procedures were evaluated in a pilot-study with 32 users of a specialized care service.In this study, field procedures, flows and suitability to health unit dynamics, sampling plan, ways of approaching women, and the quality of interviews conducted by interviewers were tested. Data from the completed questionnaires in the pilot study were not used.

In the context of the GENIH study, abortion was analyzed according to the pregnancy's context, women's age, use of contraceptive method, reasons for pregnancy when using contraceptive method, motives for nonuse, the financial situation and the situation ofthe relationship with the partner at the time of pregnancy, the woman's age at the time of abortion, the couple's agreement on the decision of aborting, the method used, the reasons for the abortion and the importance of HIV infection in this decision.

Results presented refer to the analysis of reports of all WLHA on the first abortion on life prior to the diagnosis of HIV infection and the first abortion after the diagnosis. When the same woman had abortions before and after diagnosis, these were accounted for at both times. Among WNLHA, we considered data on the single abortion in life, and the first abortion when more than one was referred.

Simple frequency measurements adjusted by the complex sampling process are presented. Women were characterized considering age at time of interview, schooling, color of skin, number of sexual lifetime partners, number of children and age at the time of diagnosis for WLHA. An association test based on the sampling strategy and weighting used (F-FisherSnedocor statistics) was conducted to assess statistically significant differences in sociodemographic characteristics between the general MVHA and MNVHA samples and among women who reported abortion. Differences in the context of first abortion among women who performed it before and/or after the diagnosis of HIV and between WNLHA were assessed by analyzing the overlapping confidence intervals of proportion measures also adjusted by the complex sampling process.

To estimate abortion underreport, an adapted version of the ballot box method was applied, asking at the end of the questionnaire: "Have you ever had an abortion in your life?" Women were asked to answer directly in the computer, with the screen turned to them, if yes or no. A key was marked with a color for "yes" and another color for "no". The magnitude of the abortion underreport was evaluated, i.e., the proportion of women that reported in the computer that they had an abortion, but did not report it to the interviewer. Sociodemographic differences in underreport were evaluated for both groups (WLHA and WNLHA) by the association test based 
on the sampling strategy and weighting used (FFisher-Snedocor statistic).

The Stata $14.0^{\circledR}$ statistical package was used for all analyzes, adjusted for complex sampling and weights used to compensate for differences in women's selection probabilities in both samples.

The study was approved by the Committees of Ethics in Research of the Reference Center of Training in STD/AIDS of the Secretary of Health of São Paulo State ( ${ }^{\circ}$ 022/2011); the Emilio Ribas Institute of Infectious Disease $\left(\mathrm{n}^{\circ}\right.$. 11712112.6.0000.5375); the Municipal Health Secretary of São Paulo ( $\left.{ }^{\circ} 0043 / 12\right)$ and São Paulo Federal University ( $\mathrm{n}^{\circ}$. 11712112.6.0000.5375).

\section{Results}

1,368 eligible WLHA were selected to compose the sample and 999 were interviewed with a loss of 369 women $(27 \%)$. Of the women interviewed, 24 were excluded for not having reported sexual initiation or for being HIV infected by vertical transmission or for having sex in life only with women. The final sample had 975 interviews with WLHA.

Of 1,334 eligible WLHA, 1,035 were interviewed with a loss of 353 women (26.5\%). Of the interviewed, 32 were excluded from the analysis for being virgins or for having sex in life only with women, totaling a final sample of 1,003 interviews with WNLHA.The main reasons for refusals were hurry/lack of time and not wanting to talk about the subject.In losses were accounted those interviewees contacted but not interviewed for leaving the health unit after the appointment or those not contacted.

The comparison of WLHA and WNLHA final samples can be found in Table 1. Compared to MNVHA, MVHA were significantly older, more self-declared as black, had less schooling, and almost a third earned up to half of a minimum wage.WLHA also reported greater number of marriages and sexual partners in life, as well as more pregnancies and living children. The higher mean age among WLHA could explain part of these sample differences to the WNLHA group.

The majority of WLHA were diagnosed between 30 and 49 years old $(43.8 \%)$; slightly over half (51\%) were diagnosed in the period from 1996 to 2006.

In all, 817 WLHA and 846 WNLHA were pregnant sometime in life, and 116 WLHA (14.2\%; CI95\% $=11.8-16.7)$ and 29 WNLHA $(3.4 \%$ $\mathrm{CI} 95 \%=2.1-4.9)$ reported at least one abortion. In all, 166 abortions were reported among WLHA, of which $66.9 \%$ reported only one abortion; 26 WLHA reported two abortions (23.1\%), nine WLHA reported three abortions (8.2\%) and two, four abortions (1.7\%). Among WNLHA, 33 lifetime induced abortions were reported; $87.0 \%$ of women reporting only one abortion and only four, more than one $(13 \%)$.

Among MVHA there were 166 abortions for 1,668 live births resulting in a ratio of 9.9 abortions per 100 live births; for WNLHA, a total of 33 abortions occurred for 1,435 live births representing 2.3 abortions per 100 live births. Adjusted for age, schooling and color of skin, the prevalence in report of induced abortions observed was $11.9 \%$ $(\mathrm{CI} 95 \%=9.8-13.9)$ among WLHA and $3.0 \%$ $(\mathrm{CI} 95 \%=2.4-5.7)$ for WNLHA $(p<0,0001)$.

The majority of abortions (128 cases) among WLHA occurred before the diagnosis of infection by HIV; 28 after the diagnosis or during pregnancy when it was given, 17 of which aborted during the first pregnancy after diagnosis. Ten WLHA reported abortions before and after the diagnosis. One legal abortion case was reported by a WVHA.

Excepting age and the number of pregnancies, variables positively correlated, WLHA and WNLHA who reported having had abortions at least once in life did not differ from the rest for the other sociodemographic variables (Table 1); however a small number of WNLHA reporting abortion harms the statistical power in evaluating significant differences.

For almost half of WLHA samples (46.6\%) and WNLHA (47.3\%) the first abortion occurred in the first pregnancy and at a similar mean age: 21 years for WLHA (amplitude: 12-24) and 22 years (amplitude: 12-34) for WNLHA (Table 2). The mean age for the first post-diagnosis abortion among WLHA is elevated to 28 years and, in general, occurs in the context of the second or third pregnancy $(29.5 \%$ and $33.6 \%$, respectively).

Most women who aborted reported not using any contraceptive method at the time of the first abortion, both among WNLHA and WLHA in abortions previous to the diagnosis. After HIV diagnosis it was observed that the first abortions occurred with the use of contraceptive method for almost half of the sample. Among those who used methods, the most reported were the reversible ones (pill and hormonal injection, implant, IUD and associations between methods), both for WNLHA and WLHA with the first abortion prior the diagnosis (Table 2). For WLHA who aborted after diagnosis even using contraception, male or female condoms were the most referred method (Table 2); the non-overlapping confidence intervals for proportions of male condom 
Table 1

Sociodemographic characteristics of WLHA and WNLHA samples from the GENIH study and those that reported life time abortion. São Paulo Municipality, 2013-2014.

\begin{tabular}{|c|c|c|c|c|c|c|c|c|}
\hline \multirow[t]{2}{*}{ Variables } & \multicolumn{2}{|c|}{$\begin{array}{l}\text { WLHA } \\
\text { general sample }\end{array}$} & \multicolumn{2}{|c|}{$\begin{array}{c}\text { WNLHA } \\
\text { general sample }\end{array}$} & \multicolumn{2}{|c|}{$\begin{array}{l}\text { WLHA with } \\
\text { abortion reports }\end{array}$} & \multicolumn{2}{|c|}{$\begin{array}{l}\text { WLHA with } \\
\text { abortion reports }\end{array}$} \\
\hline & $\mathrm{n}$ & $\% *$ & $\mathrm{n}$ & $\%$ * & $\mathrm{n}$ & $\%^{*}$ & $\mathrm{n}$ & $\% *$ \\
\hline Total (n) & 916 & & 1003 & & 116 & & 29 & \\
\hline \multicolumn{9}{|l|}{ Age at the time of interview (years) } \\
\hline $18-34$ & 196 & 26.3 & 330 & 60.1 & 6 & 4.8 & 5 & 27.3 \\
\hline \multirow[t]{2}{*}{$35-49$} & 680 & 73.7 & 416 & 39.9 & 110 & 95.2 & 23 & 72.7 \\
\hline & & $p<0.001$ & & & & $p=0.005$ & & \\
\hline \multicolumn{9}{|l|}{ Age at time of diagnosis (years) } \\
\hline Younger than 25 & 255 & 28.1 & 0 & - & 16 & 13.7 & 0 & - \\
\hline $25-29$ & 248 & 28.1 & 0 & - & 31 & 27.1 & 0 & - \\
\hline $30-49$ & 402 & 43.8 & 0 & - & 65 & 59.2 & 0 & - \\
\hline \multicolumn{9}{|l|}{ Color of skin } \\
\hline White & 373 & 39.9 & 391 & 39.1 & 50 & 42.9 & 13 & 44.7 \\
\hline Black & 158 & 17.9 & 107 & 10.7 & 20 & 17.6 & 3 & 10.0 \\
\hline Brown & 368 & 40.2 & 473 & 47.1 & 42 & 36.3 & 10 & 35.3 \\
\hline \multirow[t]{2}{*}{ Other } & 16 & 1.5 & 31 & 3.0 & 4 & 3.1 & 3 & 9.9 \\
\hline & & $p<0.001$ & & & & $p=0.334$ & & \\
\hline \multicolumn{9}{|l|}{ Schooling } \\
\hline Incomplete elementary & 247 & 27.0 & 204 & 20.2 & 36 & 31.2 & 8 & 26.4 \\
\hline Complete elementary & 234 & 25.3 & 247 & 24.8 & 24 & 20.6 & 4 & 12.3 \\
\hline High school complete & 294 & 31.9 & 435 & 43.3 & 33 & 28.1 & 12 & 44.4 \\
\hline \multirow[t]{2}{*}{ Superior (complete and incomplete) } & 143 & 15.7 & 116 & 11.6 & 23 & 20.1 & 5 & 16.9 \\
\hline & & $p=0.001$ & & & & $p=0.505$ & & \\
\hline \multicolumn{9}{|l|}{ Household per capita income (monthly) } \\
\hline Up to half minimum salary & 255 & 27.8 & 302 & 29.9 & 33 & 26.9 & 6 & 18.7 \\
\hline From half to $1 \mathrm{MS}$ & 281 & 30.5 & 351 & 35.5 & 40 & 36.6 & 11 & 37.8 \\
\hline More than $1 \mathrm{MS}$ & 382 & 41.6 & 350 & 34.5 & 43 & 36.4 & 12 & 43.4 \\
\hline \multirow[t]{2}{*}{$\mathrm{DK} / \mathrm{DR} / \mathrm{NI} \mathrm{I}^{* *}$} & 80 & 9.3 & 79 & 7.8 & 8 & 7.0 & 2 & 7.5 \\
\hline & & $p=0.083$ & & & & $p=0.777$ & & \\
\hline \multicolumn{9}{|l|}{ Number of partners in life } \\
\hline $1-2$ partners & 141 & 15.7 & 463 & 46.0 & 2 & 1.5 & 3 & 8.5 \\
\hline 3-5 partners & 406 & 44.5 & 383 & 38.6 & 40 & 35.7 & 12 & 45.4 \\
\hline 6 or more partners & 299 & 33.2 & 138 & 14.1 & 58 & 51.0 & 12 & 39.5 \\
\hline \multirow[t]{2}{*}{$\mathrm{DK} / \mathrm{DR} / \mathrm{N} \mathrm{I}^{* *}$} & 59 & 6.6 & 12 & 1.2 & 13 & 11.8 & 2 & 6.7 \\
\hline & & $p<0.001$ & & & & $p=0.069$ & & \\
\hline \multicolumn{9}{|l|}{ Number of marriages } \\
\hline Was never married & 72 & 7.8 & 154 & 15.8 & 7 & 5.7 & 3 & 10.0 \\
\hline Only once & 415 & 45.8 & 622 & 61.2 & 40 & 35.4 & 12 & 38.8 \\
\hline \multirow[t]{2}{*}{ Twice or more } & 224 & 46.4 & 425 & 23.0 & 68 & 58.9 & 14 & 51.5 \\
\hline & & $p<0.001$ & & & & $p=0.604$ & & \\
\hline \multicolumn{9}{|l|}{ Number of pregnancies } \\
\hline Never got pregnant & 101 & 10.8 & 157 & 15.6 & - & - & - & \\
\hline Once & 189 & 23.4 & 290 & 34.4 & 8 & 6.1 & 5 & 15.5 \\
\hline Twice & 223 & 26.9 & 244 & 28.9 & 19 & 16.3 & 10 & 36.4 \\
\hline \multirow[t]{2}{*}{ Three or more } & 405 & 49.6 & 312 & 36.7 & 89 & 77.6 & 14 & 48.0 \\
\hline & & $p<0.001$ & & & & $p=0.003$ & & \\
\hline
\end{tabular}

$* \%=$ weight-adjusted proportions derived from the sampling process, * $*$ DK/DR/NI= doesn't know/doesn't remember/no information, $p=p$ value, WLHA=Women living withHIVIAIDS, WNLHA= Women not living with HIVIAIDS, MS=Minimum-salary, GENIH=Gender and Infection by HIV. 
Sociodemographic characteristics of WLHA and WNLHA samples from the GENIH study and those that reported life time abortion. São Paulo Municipality, 2013-2014.

\begin{tabular}{|c|c|c|c|c|c|c|c|c|}
\hline \multirow[t]{2}{*}{ Variables } & \multicolumn{2}{|c|}{$\begin{array}{c}\text { WLHA } \\
\text { general sample }\end{array}$} & \multicolumn{2}{|c|}{$\begin{array}{c}\text { WNLHA } \\
\text { general sample }\end{array}$} & \multicolumn{2}{|c|}{$\begin{array}{l}\text { WLHA with } \\
\text { abortion reports }\end{array}$} & \multicolumn{2}{|c|}{$\begin{array}{l}\text { WLHA with } \\
\text { abortion reports }\end{array}$} \\
\hline & $\mathrm{n}$ & $\%$ * & $\mathrm{n}$ & $\%$ * & $\mathrm{n}$ & $\%$ * & $\mathrm{n}$ & $\%$ * \\
\hline \multicolumn{9}{|c|}{ Number of living children } \\
\hline None & 162 & 7.4 & 319 & 19.4 & 15 & 11.9 & 8 & 28.2 \\
\hline One & 261 & 32.3 & 267 & 32.0 & 30 & 26.7 & 9 & 30.9 \\
\hline Two & 247 & 30.3 & 233 & 27.3 & 27 & 23.5 & 5 & 21.2 \\
\hline \multirow[t]{2}{*}{ Three or more } & 248 & 30.0 & 184 & 21.3 & 44 & 37.9 & 7 & 19.6 \\
\hline & & $p<0.001$ & & & & $p=0.084$ & & \\
\hline
\end{tabular}

$* \%=$ weight-adjusted proportions derived from the sampling process, ** DK/DR/NI= doesn't know/doesn't remember/no information, $p=p$ value, WLHA=Women living withHIVIAIDS, WNLHA= Women not living with HIVIAIDS, MS=Minimum-salary, GENIH=Gender and Infection by HIV.

use at the time of abortion suggests differences in their use before and after diagnosis.

Among women who did not use contraceptive method at the time of first abortion, the main reason alleged was not to consider the possibility of getting pregnant or not worry about it, there seems not to be any difference between groups, followed by not planning to have sexual intercourse, reported by $20.5 \%$ of WLHA in the first abortion post-diagnosis and $19.8 \%$ for WNLHA (Table 2). For more than half of WLHA who used contraceptive method, pregnancy that resulted in the first abortion, both before and after diagnosis, occurred by failure in the method, including condom breakage or slip. Among the eight WNLHA who got pregnant in the context of using contraception, to four women, pregnancy occurred due to discontinuation of the method, three referred a failure of the method and one alleged "another' reason.

Aspects of conjugal behavior on the first pregnancy that resulted in abortion seem to be similar among WLHA (before diagnosis) and WNLHA; almost $70 \%$ did not live with the partner. The majority of WLHA, before and after diagnosis, and of WNLHA reported that the situation of the relationship with the partner at the time of the first abortion was stable, without crisis.

Data seem to show differences in the financial state at the occasion of the first abortion among WLHA and WNLHA, particularly when comparing WNLHA to WLHA who aborted after diagnosis. The existence of financial difficulties was reported by more than half of WNLHA, while among WLHA who aborted after diagnosis, the financial state was very difficult to $9.5 \%$ only (Table 2 ).

The partner's participation in the decision for abortion suggests similarities among WLHA and
WNLHA. A consensual decision was reported by the majority of respondents, although disagreements were cited by $25.5 \%$ of WLHA (before diagnosis) and $27.7 \%$ of WNLHA, but without statistically significant differences (Table 2). A considerable fraction of WLHA and WNLHA reported they did not inform the partner about pregnancy at the time of the first abortion.

Lack of desire for maternity during pregnancy that resulted in abortion was the reason for more than a third of women of both groups to have an abortion, followed by not living or being married with the partner. However, if the reasons to have the first abortion among WLHA, before HIV diagnosis, seem to be similar to those among WNLHA, after diagnosis, the non-desire to have children seems to be linked to the sexual-affective partnership, since $37.4 \%$ of WLHA reported as reason for aborting not wanting to have (another) child from the partner they had at the time. The non-acceptance of pregnancy by the woman's relatives and/or partner of WLHA with abortion experience after diagnosis also occupies a prominent position (Table 2).

HIV was referred as a very important factor in the decision of aborting by $47.6 \%$ of WLHA, but for an expressive portion (37.4\%) it was mentioned as minimally or not important for the decision.

The use of misoprostol, ingested or introduced in the vagina, was the most referred method among WLHA and WNLHA for inducing the abortion. There does not seem to be any statistically significant differences between WLHA and WNLHA as to the other methods used for abortion. The combined use of misoprostol with some natural method, as tea, herbs or infusions was quoted by $23.8 \%$ (22) of WLHA. Among WNLHA, all referred having used one single method, one fourth of them quoted the use 
Life contexts at the time of the first abortion between WLHA and WNLHA of the GENIH study. São Paulo Municipality, 2013-2014.

\begin{tabular}{|c|c|c|c|c|c|c|c|c|c|}
\hline & \multicolumn{3}{|c|}{$\begin{array}{l}\text { Women with abortion } \\
\text { before HIV }\end{array}$} & \multicolumn{3}{|c|}{$\begin{array}{c}\text { Women with abortion } \\
\text { after HIV }\end{array}$} & \multicolumn{3}{|c|}{ WNLHA } \\
\hline & $\mathrm{n}$ & $\%$ & $\mathrm{Cl} 195 \%$ * & $\mathrm{n}$ & $\%$ & $\mathrm{Cl} 195 \% *$ & $\mathrm{n}$ & $\%$ & $\mathrm{Cl} 195 \% *$ \\
\hline Total of women (n) & 102 & & & 24 & & & 29 & & \\
\hline \multicolumn{10}{|l|}{ Frequency of abortions } \\
\hline Only one abortion & 76 & 8.2 & $6.5-10.1$ & 20 & 2.3 & $1.4-3.5$ & 25 & 2.8 & $1.8-4.4$ \\
\hline More than one abortion & 26 & 2.9 & $1.9-4.2$ & 4 & 0.4 & $0.2-1.1$ & 4 & 0.4 & $0.2-1.1$ \\
\hline Total abortions (n) & 128 & & & 28 & & & 33 & & \\
\hline \multicolumn{10}{|l|}{ Mean age when first abortion } \\
\hline occurred (amplitude) & 21 & $12-32$ & & 28 & $22-42$ & & 22 & $12-34$ & \\
\hline \multicolumn{10}{|l|}{$\begin{array}{l}\text { Use of contraceptive method at the } \\
\text { time of } 1 \text { st abortion }\end{array}$} \\
\hline yes & 35 & 37.7 & $28.3-48.2$ & 10 & 48.7 & $28.1-69.7$ & 8 & 36.3 & $16.1-62.7$ \\
\hline No & 55 & 59.4 & $48.8-69.1$ & 9 & 45.4 & $25.4-66.9$ & 19 & 63.7 & $37.3-83.8$ \\
\hline $\mathrm{DK} / \mathrm{DR} / \mathrm{NI} I^{* *}$ & 2 & 2.8 & $0.7-10.8$ & 1 & 6.0 & $0.8-32.4$ & 0 & - & - \\
\hline \multicolumn{10}{|l|}{ Used contraceptive method } \\
\hline Masculine/feminine condom & 8 & 23.8 & $12.3-41.1$ & 8 & 80.4 & $46.4-95.1$ & 1 & 17.9 & $3.1-60.0$ \\
\hline \multicolumn{10}{|l|}{ Reversible (pill / IUD / injectable } \\
\hline / combinations) & 18 & 48.9 & $33.0-65.0$ & 2 & 19.6 & $4.9-53.6$ & 7 & 82.0 & 39.9-96.9 \\
\hline Coitus & 6 & 15.7 & 7.0-31.4 & 0 & - & - & 0 & - & - \\
\hline Outher & 3 & 8.1 & $2.6-22.4$ & 0 & - & - & 0 & - & - \\
\hline $\mathrm{DK} / \mathrm{DR} / \mathrm{NI} I^{* *}$ & 1 & 3.4 & $0.5-20.7$ & 0 & - & - & 0 & - & - \\
\hline \multicolumn{10}{|l|}{ Reason for not using contraceptive method ${ }^{1}$} \\
\hline \multicolumn{10}{|l|}{ Did not think would get pregnant/ } \\
\hline did not worry about it & 38 & 65.6 & $52.5-76.7$ & 6 & 66.7 & $32.9-89.1$ & 9 & 57,6 & $29.9-81.2$ \\
\hline \multicolumn{10}{|l|}{ Getting pregnant would } \\
\hline not be a problem & 4 & 6.2 & $2.3-15.6$ & 0 & - & - & 1 & 4,9 & $0.6-29.6$ \\
\hline Had not planned sexual intercourse & 4 & 5.1 & $1.8-13.1$ & 2 & 20.5 & $5.1-55.6$ & 4 & 19,8 & $6.3-47.9$ \\
\hline \multicolumn{10}{|l|}{ Had interrupted the use of } \\
\hline contraceptive method recently & 2 & 3.5 & $0.8-13.1$ & 0 & - & - & 3 & 14.0 & $4.4-36.8$ \\
\hline \multicolumn{10}{|l|}{ Partner did not like she used } \\
\hline contraceptive method & 1 & 1.5 & $0.2-10.3$ & 0 & - & - & 1 & 3.5 & $0.5-19.6$ \\
\hline Other reasons & 6 & 8.4 & $3.5-19.1$ & 0 & - & - & 0 & - & - \\
\hline $\mathrm{DK} / \mathrm{DR} / \mathrm{NI} \mathrm{I}^{* *}$ & 5 & 9.0 & $3.7-20.1$ & 1 & 12.8 & $1.8-54.4$ & 2 & NC & \\
\hline \multicolumn{10}{|l|}{ Reason reported for pregnancy occurring } \\
\hline \multicolumn{10}{|l|}{ during use of contraceptive method } \\
\hline \multicolumn{10}{|l|}{ Forgot/stopped using the } \\
\hline pill (interruption) & 6 & 15.3 & $6.9-30.3$ & 0 & - & - & 4 & 50.8 & $25.3-75.9$ \\
\hline \multicolumn{10}{|l|}{ Failure of method (condom broke, } \\
\hline coitus interruptus failed) & 21 & 57.3 & $40.8-72.3$ & 7 & 68.1 & $35.3-89.3$ & 3 & 31.2 & $5.4-78.2$ \\
\hline Did not use condom in all intercourses & 2 & 5.1 & $1.3-18.5$ & 3 & 31.8 & $10.7-64.7$ & 0 & - & - \\
\hline Other reason & 4 & 10.5 & $3.9-25.0$ & 0 & - & - & 1 & 17.9 & $3.1-60.1$ \\
\hline $\mathrm{DK} / \mathrm{DR} / \mathrm{N} \mathrm{I}^{* *}$ & 4 & 11.8 & $4.4-28.0$ & 0 & - & - & 0 & - & - \\
\hline \multicolumn{10}{|l|}{$\begin{array}{l}\text { Lived with partner of pregnancy which } \\
\text { resulted in the } 1 \text { st abortion }\end{array}$} \\
\hline Yes & 30 & 29.2 & $21.0-39.0$ & 8 & 57.6 & $31.9-79.8$ & 9 & 31.8 & $21.1-44.9$ \\
\hline No & 69 & 70.8 & $61.0-78.9$ & 6 & 42.3 & $20.2-68.1$ & 20 & 68.1 & $55.1-78.8$ \\
\hline
\end{tabular}

$* \%=$ weight-adjusted proportions derived from the sampling process; ** DK/DR/NI= doesn't know/doesn't remember/not informed; NC=not calculated; $1 \mathrm{ACM}=$ anticonception method; $\mathrm{C} 195 \%=95 \%$ confidence interval adjusted for weights derived from complex sampling process, HIV=Human Acquired Immunodeficiency syndrome Virus; WLHA=women living with HIV/AIDS; WNLHA=women not living with HIV/AIDS; GENIH=gender and infection by HIV. 
Life contexts at the time of the first abortion between WLHA and WNLHA of the GENIH study. São Paulo Municipality, 2013-2014.

\begin{tabular}{|c|c|c|c|c|c|c|c|c|c|}
\hline & \multicolumn{3}{|c|}{$\begin{array}{l}\text { Women with abortion } \\
\text { before HIV }\end{array}$} & \multicolumn{3}{|c|}{$\begin{array}{l}\text { Women with abortion } \\
\text { after HIV }\end{array}$} & \multicolumn{3}{|c|}{ WNLHA } \\
\hline & $\mathrm{n}$ & $\%$ & $\mathrm{Cl} 195 \% *$ & $\mathrm{n}$ & $\%$ & $\mathrm{Cl} 195 \%$ * & $\mathrm{n}$ & $\%$ & $\mathrm{Cl} 195 \%$ * \\
\hline \multicolumn{10}{|l|}{ Relationship status with abortion partner } \\
\hline Was beginning & 18 & 20.0 & $12.9-29.6$ & 3 & 12.4 & $3.9-32.7$ & 7 & 27.1 & $13.8-46.3$ \\
\hline Was stable & 57 & 58.9 & 48.4-68.6 & 11 & 53.3 & $32.4-73.1$ & 14 & 47.0 & $23.1-72.5$ \\
\hline Was unstable/ in a crisis & 16 & 17.8 & $11.1-27.4$ & 4 & 17.8 & $6.8-39.4$ & 6 & 25.8 & $11.8-47.7$ \\
\hline $\mathrm{DK} / \mathrm{DR} / \mathrm{NI} \mathrm{I}^{* *}$ & 3 & 3.2 & $0.5-8.3$ & 2 & 16.4 & $5.4-40.4$ & 2 & NC & \\
\hline \multicolumn{10}{|l|}{ Financial situation when discovered pregnancy } \\
\hline Good, reasonable & 41 & 41.9 & $32.2-52.3$ & 14 & 70.2 & $47.3-86.0$ & 3 & 10.8 & $4.0-26.1$ \\
\hline A little difficult & 20 & 21.9 & $14.5-31.7$ & 3 & 14.3 & $4.6-36.4$ & 7 & 25.5 & $11.7-47.1$ \\
\hline Very difficult & 31 & 32.9 & $24.1-43.3$ & 2 & 9.5 & $2.4-31.3$ & 17 & 56.6 & $38.5-73.1$ \\
\hline $\mathrm{DK} / \mathrm{DR} / \mathrm{N} \mathrm{I}^{* *}$ & 2 & 2.1 & $0.5-8.2$ & 1 & 5.9 & $0.8-32.4$ & 2 & 7.1 & $2.1-21.3$ \\
\hline \multicolumn{10}{|l|}{ In the decision of interrupting pregnancy } \\
\hline She and her partner agreed & 34 & 36.3 & $27.1-46.7$ & 7 & 28.3 & $13.9-49.1$ & 11 & 38.1 & $27.8-49.7$ \\
\hline She wanted but he did not & 13 & 13.8 & $8.1-22.7$ & 2 & 10.2 & $2.6-32.5$ & 6 & 17.2 & 7.9-33.4 \\
\hline He wanted but she did not & 10 & 11.7 & $6.3-20.5$ & 2 & 8.1 & $2.0-27.4$ & 3 & 10.5 & 4.1-24.2 \\
\hline Partner allowed her to decide & 9 & 8.7 & $4.5-15.9$ & 3 & 13.2 & $4.3-34.2$ & 2 & 7.5 & $1.8-25.7$ \\
\hline Partner was not informed of pregnancy & 26 & 27.4 & $19.2-37.4$ & 4 & 16.3 & $6.2-36.5$ & 5 & 20.1 & $9.4-37.7$ \\
\hline Outher & 1 & 1.1 & $0.1-7.1$ & 3 & 12.9 & $4.2-33.8$ & 1 & 3.1 & $0.4-19.8$ \\
\hline $\mathrm{DK} / \mathrm{DR} / \mathrm{NI} \mathrm{I}^{* *}$ & 1 & 1.1 & $0.1-7.1$ & 1 & 10.9 & $2.7-34.5$ & 1 & 3.5 & $0.4-23.7$ \\
\hline \multicolumn{10}{|c|}{ How abortion was accomplished (multiple answer) } \\
\hline Use of misoprostol & 63 & 64.1 & $54.0-73.1$ & 19 & 70.2 & $49.6-84.9$ & 12 & 46.8 & $22.4-73.0$ \\
\hline By curettage & 18 & 18.9 & $12.1-28.3$ & 4 & 15.4 & $5.8-34.8$ & 3 & 11.4 & 2.7-37.8 \\
\hline By aspiration (vacuum, suction) & 5 & 5.8 & $2.4-13.2$ & 2 & 8.2 & $2.0-27.9$ & 0 & - & - \\
\hline \multicolumn{10}{|l|}{ With use of objects (needle, } \\
\hline probe, catheter) & 12 & 12.9 & $7.3-21.3$ & 0 & - & - & 1 & 3.2 & $0.4-20.5$ \\
\hline With teas, infusions and herbs & 13 & 13.8 & $7.9-22.8$ & 3 & 11.1 & $3.5-29.9$ & 8 & 24.9 & $11.2-46.8$ \\
\hline Outher form & 12 & 12.9 & $7.5-21.4$ & 3 & 11.7 & $3.8-30.9$ & 2 & 5.9 & $1.4-21.4$ \\
\hline Other medicines (except misoprostol) & 2 & 1.6 & $0.4-6.5$ & 1 & 3.8 & $0.5-22.0$ & 2 & 7.6 & $1.7-28.0$ \\
\hline \multicolumn{10}{|l|}{ Main reason that weighed on abortion decision } \\
\hline \multicolumn{10}{|l|}{ Was not married/did not life together/ } \\
\hline was without partner & 20 & 22.1 & $14.6-32.0$ & 3 & 13.2 & $4.3-34.2$ & 7 & 23.6 & $9.9-46.4$ \\
\hline \multicolumn{10}{|l|}{ She and/or partner could not } \\
\hline afford the child & 12 & 13.2 & $7.5-21.9$ & 0 & - & - & 4 & 15.1 & 3.7-45.5 \\
\hline \multicolumn{10}{|l|}{ Family and / or family members of } \\
\hline partner would not accept pregnancy & 16 & 18.1 & $11.3-27.7$ & 4 & 17.1 & $6.5-37.9$ & 4 & 14.0 & $3.0-46.2$ \\
\hline She did not want a child at that moment & 19 & 19.0 & $12.3-28.3$ & 2 & 8.1 & $2.0-27.4$ & 8 & 31.1 & $16.5-50.6$ \\
\hline $\begin{array}{l}\text { Partner did not want a child at } \\
\text { that moment }\end{array}$ & 8 & 8.6 & $4.3-16.7$ & 2 & 8.1 & $2.0-27.5$ & 2 & 6.8 & 2.6-16.5 \\
\hline \multicolumn{10}{|l|}{ She did not want (another) child } \\
\hline from that partner & 12 & 12.0 & $6.9-20.2$ & 9 & 37.4 & $20.4-58.3$ & 1 & 3.2 & $0.4-20.5$ \\
\hline Suffered violence from partner & 5 & 5.8 & $2.4-13.4$ & 0 & - & - & 1 & 3.2 & $0.4-20.5$ \\
\hline Outher reason & 1 & 1.1 & $0.1-7.2$ & 1 & 5.1 & $0.7-28.7$ & 1 & 3.1 & $0.4-21.2$ \\
\hline $\mathrm{DK} / \mathrm{DR} / \mathrm{N} \mathrm{N}^{* *}$ & 0 & - & - & 1 & 10.9 & $2.7-34.5$ & 0 & - & - \\
\hline
\end{tabular}

continue

*\% = weight-adjusted proportions derived from the sampling process; * DK/DR/NI= doesn't know/doesn't remember/not informed; NC=not calculated; $1 \mathrm{ACM}=$ anticonception method; $\mathrm{CI} 95 \%=95 \%$ confidence interval adjusted for weights derived from complex sampling process, HIV=Human Acquired Immunodeficiency syndrome Virus; WLHA=women living with HIVIAIDS; WNLHA=women not living with HIVIAIDS; GENIH=gender and infection by HIV. 
Life contexts at the time of the first abortion between WLHA and WNLHA of the GENIH study. São Paulo Municipality, $2013-2014$.

\begin{tabular}{|c|c|c|c|c|c|c|c|c|c|}
\hline & \multicolumn{3}{|c|}{$\begin{array}{c}\text { Women with abortion } \\
\text { before HIV }\end{array}$} & \multicolumn{3}{|c|}{$\begin{array}{c}\text { Women with abortion } \\
\text { after HIV }\end{array}$} & \multicolumn{3}{|c|}{ WNLHA } \\
\hline & $\mathrm{n}$ & $\%$ & $\mathrm{Cl} 95 \%$ * & $\mathrm{n}$ & $\%$ & $\mathrm{Cl} 95 \%$ * & $\mathrm{n}$ & $\%$ & $\mathrm{Cl} 95 \%$ * \\
\hline \multicolumn{10}{|l|}{ In the decision to abort, HIV: } \\
\hline Was very important & - & - & - & 11 & 47.6 & $28.4-67.6$ & - & - & - \\
\hline Was important & - & - & - & 1 & 4.1 & $5.6-24.1$ & - & - & - \\
\hline Was of little importance & - & - & - & 3 & 12.2 & $3.9-31.9$ & - & - & - \\
\hline Was not important & - & - & - & 6 & 25.2 & $11.6-46.3$ & - & - & - \\
\hline $\mathrm{DK} / \mathrm{DR} / \mathrm{NI}$ ** & - & - & - & 1 & 10.9 & $2.7-34.5$ & - & - & - \\
\hline
\end{tabular}

*\% = weight-adjusted proportions derived from the sampling process; * DK/DR/NI= doesn't know/doesn't remember/not informed; $\mathrm{NC}=$ not calculated; $1 \mathrm{ACM}=$ anticonception method; $\mathrm{Cl} 95 \%=95 \%$ confidence interval adjusted for weights derived from complex sampling process, HIV=Human Acquired Immunodeficiency syndrome Virus; WLHA=women living with HIV/AIDS; WNLHA=women not living with HIVIAIDS; GENIH=gender and infection by HIV.

of teas, infusions or herbs.

One telling instance about potential effects of abortion stigma and criminalization was the underreporting of abortion in both samples of women. When comparing reports of the practice during face-to-face interviews and the response given in the computer by the woman herself, we verify that 42 WLHA $(6.1 \%$; CI95\%=4.5-8.2) and $34(4.2 \%$; CI95\%=2.86.3) WNLHA who reported to the interviewer they had not had an abortion in life, answered, in the electronic ballot box, that, in fact they had had an abortion. This heightens from 116 to 158 among WLHA and from 29 to 63 among WNLHA the number of women who have had an abortion sometime in life. This represents a prevalence of abortion found by the ballot box method of $16.5 \%(\mathrm{CI} 95 \%=14.1-19.2)$ for WLHA and $7.1 \%(\mathrm{CI} 95 \%=5.5=9.0)$ for WNLHA, maintaining the statistically significant difference between groups. The ratio between the two methods (direct question and adapted ballot box method) was 1.17 for WLHA and 2.2 for WNLHA, that is, for the latter the prevalence of induced abortion obtained from the adapted ballot box method was more than twice that observed by the direct method. When analyzing sociodemographic differences between WLHA and WNLHA that underreported abortion practices, statistically significant differences were not observed between groups.

\section{Discussion}

The results revealed that the magnitude of the occurrence of lifetime abortion among WLHA was four times that observed in WNLHA. When analyzing prevalence before and after diagnosis of HIV, 15.8\% of WLHA reported aborting prior to HIV; this proportion diminished to $6.1 \%$ after diagnosis, even so, twice as that observed for WNLHA, even after adjusting by age, schooling and color of skin. 13 More recent data on abortion in Brazil, however, using population samples show different prevalence; $2.1 \%$ in a population sample of women between 18 and 49 years old in the National Health Research conducted in the same year as the GENIH ${ }^{14}$ study and $13 \%$ of abortion sometime in life among women from 18 to 39 years old in a research by Diniz et al., 9 with a representative sample of the female population in 2016. However, methodological differences, particularly related to the sampling and region under study (São Paulo and Brazil) limit any comparison of prevalence observed in this study with those referred by national studies.

Although WLHA are older and begin sexual life earlier in relation to WNLHA, thus accumulating more reproductive events, when stratifying by age group the WLHA still remain with higher prevalence of lifetime abortion. Thus, part of this difference may be explained by a higher exposure to situations of vulnerability to HIV and recurrent unplanned pregnancies amongWLHA in their life trajectories.

Nevertheless, despite the difference in magnitude, the reasons reported for the abortion by WLHA and WNLHA are similar. More than half abortions in both segments occurred in the context of not using contraception due to the perception of interviewees that they were not going to get pregnant or did not worry about this. That is, the possibility of pregnancy was not considered, suggesting that reproductive life planning may not be urgent, possible or makes no sense in the context and contingencies of the women's lives. Other studies point out that many women do not use contraception even facing the 
unwillingness or intention of having children at a certain moment, or by the fear of becoming infertile. These data reinforce the idea that ambivalences towards desire and reproductive planning are common and attest the complexity of maternity and reproduction, for being events strongly marked by social, economic and cultural issues. 15,16

On the other extreme, there are abortion cases that derive from a pregnancy occurring while using contraception. More than a third of interviewees reported the method's discontinuity or failure as the main reason given in the circumstance. This, once again, reiterates the difficulties surrounding the use of contraception, demanding orientation and accompaniment of contraceptive attention. Almost half of WLHA who aborted after diagnosis, got pregnant using some method - condom in the majority of cases - suggesting the possibility of a flawed use of the method or difficulties in their negotiation with the partner.As 15 of 24 WLHA had a serodiscordant partner at the time of the first post-diagnosis abortion, women and health services may have prioritized prevention of sexual transmission to their partner instead of a similar concern to pregnancy prevention. Other studies indicate the non-use of contraceptive method among serodiscordant couples for different reasons, 17 reiterating the need of associating condoms to another modern contraceptive method to avoid non-intentional pregnancy among WLHA. 18

To the majority of WLHA and WNLHA the noncohabitation with the partner, financial difficulties and lack of support from the families were the main reasons for aborting. Not-being in a stable or marital relationship may have been determinant also for not using contraception. An analysis of the contraceptive trajectory of French women six months prior to abortion, at the time of abortion and one month after, shows that women who used the same method, a more effective one, such as hormonal, in these three moments, were those who had stable relationships for more than one year. ${ }^{19}$ Having a stable partner or being married with the pregnancy partner seems to be fundamental for the maintenance or interruption of pregnancy, as also show other studies. ${ }^{20-22}$

If, on the one hand, the conjugality situation is important in the decision to abort, to a significant number of women this decision does not require the partner's knowledge and participation. In a smaller number, abortion situations in which the partner let the woman decide by herself may reflect both respect to the women's decision and non-responsibility in the decision making process.

The consensual decision on abortion by the woman and her partner was the most common situation reported both by WLHA and WNLHA. The disaccord in the decision occurred to more than one fifth of WLHA and WNLHA, being more frequent in the sense of woman wanting to interrupt while the partner did not. Effecting abortion in these cases suggests that the women's decision prevailed, even if such situations should be understood in the interface with other factors, such as social class, life cycle and the relationship situation, which determine greater or lesser consensus-seeking in abortion decisions.

The unwillingness to have children at that moment in life was one of the main reasons reported by women for having the first abortion. Added to these cases, are cases where women did not desire other children with the pregnancy partner, particularly among WLHA, suggesting that if they got pregnant by another partner, they may have carried out the pregnancy. Such data on one hand reiterate the importance and /or adequacy of partnership for maintaining pregnancy, on the other, reveal that the unwillingness to have children, in contrast to gender conventions that evoke motherhood as a natural choice in the female trajectory, is common and should be welcomed and respected by professionals and society.

The abortion itineraries for both groups are similar, with the use of misoprostol being the most referred, such as in other studies. The consumption of teas, herbs, infusions was cited, particularly among WNLHA, being a relatively common practice, whether or not in conjunction with medicalized forms of abortion, as other studies attest.

As for the influence of HIV in the decision of aborting, to half of WLHA, HIV was "very important". Although its reason was not questioned, some studies suggest that doubts and insecurities on breastfeeding, self-care and related to the child facing the risk of getting ill, dying and fear of HIV transmission to the fetus, despite access to treatment and consequent reduction of this risk, are reasons mentioned by WLHA. However, it should be noted that, in our study, when spontaneously responding to what weighed in the decision to abort, no MVHA cited the infection. In addition, for an expressive number of WLHA, HIV was of little importance in the decision for abortion, suggesting that other life situations had a greater weight. In the trajectory analysis of 18 women who aborted after diagnosis, Pilleco et al. 21 observed that HIV was referred as the main reason for aborting. Nevertheless, other adverse situations influenced the decision, as the lack of financial conditions, woman's or partner's 
unwillingness to have more children and the relationship situation with the partner, reasons similar to those found in the present paper.

Abortion underreport occurred to both groups without statistically significant magnitude differences. Conversely, when comparing the prevalence of abortion obtained by both methods in each group of women, the number of WNLHA who referred in the "ballot box" having had an abortion was more than twice of the prevalence of abortion observed by the direct method in this segment. For WLHA, the difference did not reach $20 \%$ when comparing methods to estimate prevalence in the reporting of abortion. The smallest difference observed between the methods may suggest that revealing the practice of abortion among women who already show an also stigmatized condition, such as HIV infection, and known by the interviewer could favor the reporting of these cases.

Non-revelation of abortion reflects the criminalization of the act and the stigma associated to women who interrupt pregnancy. The persistence of the stigma related to HIV, articulated to stigmatization and criminalization of abortion doubly engender the silence of the experiences and the exposure to risks. In this study, not only a portion of women denied abortion induction during the interview, as well as omitted pregnancy and the decision of aborting to partners and family, experiencing abortion in a silent and solitary way, as observed in other studies.

Despite studies showing that estimates on the number of abortions annually in Brazil could be close to one million, with high incidence and costs to the public health system, the stigma and discrimination involving its practice perpetuates a cycle of silence or "public silence" that prevents women from reporting such practice in researches, in health care services, or in their closer social network. Underreports contribute to the social construction of abortion as a non-normative practice and, therefore, deviant and subject to discrimination processes. Criminalization and stigma have major roles in the permanence of this "public-secret" and the silencing of abortion even in researches compromised ethically with participants, because they operate anchored in morality and normativity involved in the construction of a "feminine identity".

Some limitations of this study should be highlighted. The little number of abortion cases, particularly in WNLHA, may have limited the statistical power to identify significant differences between groups. Thus, one should be careful in interpreting results of this descriptive study even if these results meet other cited studies that reiterate the presence of more similarities than differences between WLHA and WNLHA regarding the context of abortion.

Another point is about the adapted "ballot box" method to estimate magnitude of under-reports, comparing prevalence obtained by this method and by the direct method. In general, researches that use ballot box method apply a general questionnaire without previous questions on abortion that are restricted to the box. In the present case, previous questions on abortion had already been asked directly to the interviewees, which could have influenced the answer given in the box.Yet, the method adopted allowed to estimate underreport and evaluate differences between the groups.

The use of samples of primary attention public health services and of specialized HIV/Aids attention network also limits any comparison between prevalence of abortion observed and those estimated in population studies. However, similitude of contexts and motives for having an abortion not connected to seropositivity shows that WLHA and WNLHA users of public health services share experiences linked to their feminine condition, many times, molded by great social and gender inequalities that affect their possibilities of access to resources and services for the prevention and promotion of their sexual and reproductive health.

In a social and political context of impacting setbacks in the guarantee of social rights, including sexual and reproductive ones, it is necessary to give visibility to the common fact an abortion is, and its impact on women's health. More than ever it is necessary to talk about abortion, publicize and share research data and alternative ways of obtaining these data, showing they are a common event in women's lives of all classes, ethnicities, ages, sexual and religious orientations, living or not with HIV/Aids.

\section{Authors' contribution}

Pinho AA conceived the paper, analyzed and interpreted data and wrote the first version of the manuscript. Villela WV contributed to the discussion and writing of the manuscript. Barbosa RM coordinated the GENIH study and participated in the manuscript's revision. Monteiro SS contributed to the discussion and revision of the manuscript. All of them approved the manuscript's final version. 


\section{References}

1. Silva BGC, Lima NP; Silva SG, Antúnez SF, Seerig LM, Restrepo-Méndez MC, Wehrmeister FC. Mortalidade materna no Brasil no período de 2001 a 2012: tendência temporal e diferenças regionais. Rev Bras Epidemiol. 2016 19 (3): 484-93.

2. Soares LR, Gonzaga CMR, Branquinho LW, Sousa AL, Rovery M, Freitas-Junior R. Mortalidade por câncer de mama feminino no Brasil de acordo com a cor. Rev Bras Ginecol Obstet. 2015; 37 (8): 388-92.

3. Brasil. Ministério da Saúde. Secretaria de Vigilância em Saúde. Departamento DST, Aids e Hepatites Virais. Boletim epidemiológico de Sífilis - 2017. Volume 48, n.36. Brasília DF; 2017.

4. d'Orsi E, Brüggemann OM, Diniz CSG, Aguiar JM, Gusman CR, Torres JA Angulo-Tuesta A, Rattner D, Domingues RMSM. Desigualdades sociais e satisfação das mulheres com o atendimento ao parto no Brasil: estudo nacional de base hospitalar. Cad Saúde Pública. 2014; 30 (Suppl. 1): S154-S68.

5. Araújo TVB, Rodrigues LC, Ximenes RAA, Miranda-Filho DB, Montarroyos UR, Melo APL, Valongueiro S, Albuquerque MFPM, Souza WV, Braga C, Filho SPB Cordeiro MT, Vazquez E, Di Cavalcanti DSC, Henriques CMP, Bezerra LCA, Silva Castanha PM, Dhalia R, Marques-Júnior ETA, Martelli CMT. Association between Zika virus infection and microcephaly in Brazil, January to May, 2016: preliminary report of a case-control study. Lancet. 2016; 16: 1356-63

6. Viellas EF, Domingues RMS, Dias MAB, Gama SGN, Gramado SN, Filha T, Miranda M, Costa JV, Bastos MH, Leal MC. Assistência pré-natal no Brasil. Cad Saúde Pública. 2014; 30 (Supl.): S85-S100.

7. Monteiro MFG, Adesse L, Drezett J. Atualização das estimativas da magnitude do aborto induzido, taxas por mil mulheres e razões por 100 nascimentos vivos do aborto induzido por faixa etária e grandes regiões. Brasil, 1995 a 2013. Reprod Clim. 2015; 30 (1): 11-8.

8. Ganatra B, Gerdts C, Rossier C, Johnson Jr BR, Tunçalp O, Assifi A, Sedgh G, Singh S, Bankole A, Popinchalk A, Bearak J, Kang Z, Alkema L. Global, regional, and subregional classification of abortions by safety, 2010-14: estimates from a Bayesian hierarchical model. Lancet. 2017; 390 (10110): 2372-81.

9. Diniz D, Medeiros M, Madeiro A. Pesquisa Nacional de Aborto - 2016. Ciênc Saúde Colet. 2017; 22 (2): 653-60.

10. Martins-Melo FR, Lima MS, Alencar CH, Ramos Jr NA, Carvalho FHC, Machado MMT. Tendência temporal e distribuição espacial do aborto inseguro no Brasil, 19962012. Rev Saúde Pública. 2014; 48 (3): 508-20.

11. Pilecco FB, Teixeira LB, Vigo Alvaro, Dewey ME, Knauth DR. Lifetime induced abortion: A comparison between women living and not living with HIV. PLoS One. 2014 9(4): e95570.

12. Barbosa RM, Pinho AA, Santos NS, Filipe E, Villela W, Aidar T. Aborto induzido entre mulheres em idade reprodutiva vivendo e não vivendo com HIV/aids no Brasil. Ciênc Saúde Colet. 2009; 14: 1085-99.
13. Pinho AA, Cabral C, Barbosa R. "Diferenças e similaridades entre mulheres que vivem e não vivem com HIV: aportes do estudo GENIH para a atenção à saúde sexual e reprodutiva". Cad Saúde Pública. 2017; 33 (12): e00057916.

14. IBGE (Instituto Brasileiro de Geografia e Estatística). Pesquisa nacional de saúde, 2013: ciclos de vida - Brasil e grandes regiões / IBGE, Coordenação de Trabalho e Rendimento. Rio de Janeiro; 2015. 92 p.

15. Borges ALV, Cavalhieri FB, Hoga LAK, Fujimori E, Barbosa LR. Planejamento da gravidez: prevalência e aspectos associados. Rev Esc Enferm USP. 2011; 45 (Esp. 2): $1679-84$.

16. Patel PR, Laz TH, Berenson AB. Patient Characteristics Associated with Pregnancy Ambivalence. J Womens Health. 2015; 24 (1): 37-41.

17. Fernandes NM, Hennington EA, Bernardes JS, Grinsztejn BG. Vulnerabilidade à infecção do HIV entre casais sorodiscordantes no Rio de Janeiro, Brasil. Cad Saúde Pública. 2017; 33 (4): e00053415.

18. Tsuyuki K, Gipson J, Urada L, Barbosa R, Morisky DE. Dual protection to address the global syndemic of HIV and unintended pregnancy in women: Factors associated with dual method use and consistent condom use in Brazil. J Fam Plann Reprod Health Care. 2016; 42 (4): 271-9.

19. Bajos N, Lamarche-Vadel A, Gilbert F, Ferrand M, Moreau C. Contraception at the time of abortion: high-risk time or high-risk women? Hum Reprod. 2006; 21 (11): 2862-7.

20. MacCarthy S, Rasanathan JJK, Crawford-Roberts A, Dourado I, Gruskin S. Contemplating abortion: HIV-positive women's decision to terminate pregnancy. Cult Health Sex. 2014; 16 (2): 190-201.

21. Pilecco FB, Teixeira LB, Vigo A, Knauth DR. Post-diagnosis abortion in women living with HIV/Aids in the south of Brazil. Ciênc Saúde Coletiva. 2015; 20 (5): 1521-30.

22. Vilella W, Barbosa RM, Portela, AP, Oliveira, L. Motivos e circunstâncias para o aborto induzido entre mulheres vivendo com HIV no Brasil. Ciênc Saúde Coletiva. 2012; 17 (7): $1709-19$

23. Heilborn M, Cabral C, Brandão ER, Cordeiro F, Azize R. Gravidez imprevista e aborto no Rio de Janeiro, Brasil: gênero e geração nos processos decisórios. Sex Salud Soc (Rio J.). 2012; 12: 224-57.

24. Diniz D, Medeiros M. Itinerários e métodos do aborto ilegal em cinco capitais brasileiras. Ciênc Saúde Coletiva. 2012; 17 (7): 1671-81.

25. Arilha MM. Misoprostol: percursos, mediações e redes sociais para o acesso ao aborto medicamentoso em contextos de ilegalidade no Estado de São Paulo. Ciênc Saúde Coletiva. 2012; 17 (7): 1785-94.

26. Madeiro AP, Rufino AC. Maus-tratos e discriminação na assistência ao aborto provocado: a percepção das mulheres em Teresina, Piauí, Brasil. 2017. Ciênc Saúde Coletiva. 2017; 22 (8): 2771-80

27. Adesse L, Jannotti CB, Silva KS, Fonseca VM. Aborto e estigma: uma análise da produção científica sobre a temática. Ciênc Saúde Coletiva. 2016; 21 (12): 3819-32. 
28. Kumar A, Hessini L, Mitchell EMH. Conceptualising abortion stigma. Cult Health Sex. 2009; 11 (6): 625-39.

29. Olinto MTA, Moreira Filho DC. Estimativa de aborto induzido: comparação entre duas metodologias. Rev Panam Salud Publica. 2004; 15 (5): 331-6.

Received on January 15, 2018

Final version presented on June 24, 2019

Approved on September 18, 2019 